\title{
MAŁE ŚWIĘTO JAKO NOŚNIK TOŻSAMOŚCI KULTUROWEJ W POWIEŚCI ТЕЛЛУРИЯ WŁADIMIRA SOROKINA
}

\author{
THE SMALL FEAST AS A MEDIUM OF CULTURAL IDENTITY \\ IN THE NOVEL ТЕЛЛУРИЯ BY VLADIMIR SOROKIN
}

\author{
ANNA STRYJAKOWSKA
}

\begin{abstract}
The article examines the category of feast in Vladimir Sorokin's novel Телирия. The proposed interpretation of selected parts of the novel leads to the conclusion that in postmodern conditions, the phenomenon of small feast might take on the role of a medium of cultural identity.

Anna Stryjakowska, Uniwersytet im. Adama Mickiewicza w Poznaniu, Poznań - Polska, a.stryjakowswka@gmail.com
\end{abstract}

W akcentującej heterogeniczność i względność dobie ponowoczesności integracja społeczeństw wokół wspólnych wartości stanowi nie lada wyzwanie, preferowane stają się poziomy lojalności inne niż te fundowane na bazie narodowej czy etnicznej, co implikuje pytanie o status święta jako medium tożsamości kulturowej. Kultura postmodernistyczna asymiluje rzecz jasna zabawowy, dekonstrukcyjny pierwiastek fenomenu. Karnawałowe odczucie świata jest niewątpliwie jedną z kluczowych kategorii interpretacyjnych $\mathrm{w}$ odniesieniu do światowej literatury postmodernistycznej, staje się również cechą kultury ponowoczesnej jako takiej (Andrzej Szahaj określa ponowoczesność mianem „czasu karnawału”1). Przestrzeń artystyczna utworów Władimira Sorokina daje się określić mianem hiperkarnawałowej, epatując poetyką skandalu, groteski, ironiczną i autoironiczną percepcją tradycji, kreując atmosferę pluralizmu i względności. Tak konstruowana narracja wydaje się ściśle sprzężona $\mathrm{z}$ orientacją ideologiczną przywiązanego do idei wolności pisarza, który, jak odnotowują literaturoznawcy², zdaje się porzucać wcześniejszą neutralną pozycję na rzecz

${ }^{1} \mathrm{~A} . \mathrm{S}$ z a h a j, Ponowoczesność - czas karnawatu, postmodernizm - filozofia błazna, [w:] Postmodernizm a filozofia. Wybór tekstów, red. S. Czerniak, A. Szahaj, Warszawa 1996.

2 Zob. пр.: М.П. М а р у с е н к о в, Абсурдопедия русской жизни Владимира Сорокина. Заумь, гротеск и абсурд, Санкт-Петербург 2012, s. 5-10; Г. Н е ф а г и н а, Возвращение вперед Владимира Сорокина, или от деструкции - к конструкции (анти)утопического мира, [w:] От модернизма к постмодернизму. Русская литература XX-XXI веков. Сборник статей $в$ честь проф. Халины Вашкелевич, ред. А. Скотницка, Я. Свежи, Краков 2014, s. 558. 
dyskretnej artykulacji swojego stanowiska wobec kondycji współczesnego człowieka i świata. Zasada ta doczekała się szczytowej realizacji w ostatniej powieści rosyjskiego pisarza pt. Теллурия ${ }^{3}$. W świetle dalszych rozważań warto zaakcentować geokulturowe rozszerzenie diapazonu literackiej refleksji postmodernisty: zyskawszy po wydaniu Dnia oprycznika i Cukrowego Kremla opinię celnego prognosty wydarzeń w Rosji, autor sytuuje akcje Tellurii również w rozmaitych zakątkach Europy Zachodniej.

W świecie artystycznym Tellurii rosyjski pisarz dokonuje swego rodzaju inwentaryzacji wspólnych dla przestrzeni europejskiej kolektywnych lęków, pragnień i nadziei, często z niemałą dozą ironii nadając literacką formę rozmaitym fobiom, prognozom i ideom towarzyszącym bieżącej debacie publicznej, a zwłaszcza dyskursowi medialnemu. Akcja powieści rozgrywa się w II połowie XXI wieku w realiach nowego średniowiecza, a dzisiejsza Rosja i Europa rozbite są na mniejsze organizmy państwowe po wyczerpujących konfliktach. W części z nich toczą się jeszcze działania wojenne, część odbudowuje swój potencjał po kilkuletniej okupacji przez islamskich fundamentalistów. Najbogatszym państwem, skupiającym uwagę niemal wszystkich bohaterów, jest rozpościerająca się w górach Ałtaju tytułowa Demokratyczna Republika Tellurii. Dysponuje ona strategicznym dla Europejczyków i świata potencjałem - to właśnie tam wydobywa się tellur, który jest powszechnie pożądanym narkotykiem, pod postacią gwoździ wbijanym do głowy przez wyspecjalizowanych cieśli.

Wyłaniająca się z mapy politycznej atmosfera dezintegracji potęgowana jest przez nietradycyjną dla gatunku kalejdoskopową strukturę dzieła, które składa się z pięćdziesięciu części zaledwie wprowadzających czytelnika $\mathrm{w}$ świat poszczególnych bohaterów - reprezentantów rozmaitych grup socjalnych, regionów geograficznych, a nawet rozmiarów i gatunków. Sorokin po raz kolejny wprowadza bohaterów w trzech "formatach" (normalnym, dużym i małym), a także postaci zoomorficzne. Każdy z nich posługuje się unikalnym językiem; lingwistyczne bogactwo dzieła potwierdza status autora jako mistrza stylizacji. Opisana atomizacja polityczna i społeczna nie doprowadziła jednakże do zupełnej erozji więzi kulturowych łączących mieszkańców Starego Kontynentu. Bogata intertekstualna przestrzeń powieści pozwala postrzegać ją nie tylko jako dystopijną wizję przyszłości, lecz także jako refleksję o europejskim dziedzictwie kulturowym. W spluralizowanym mikrokosmosie Tellurii można bowiem odnaleźć szereg elementów konstytuujących wspólną przestrzeń tożsamościową. Tym najbardziej oczywistym jest wspomniana potrzeba tellurowego transu, przed którą nie powstrzymuje nawet stosunkowo duże prawdopodobień-

${ }^{3}$ Powieść nie została jak dotąd przetłumaczona na język polski; by zachować przejrzystość wywodu, będę jednak używać spolszczonej wersji tytułu: Telluria. 
stwo śmierci. Pozytywnym elementem formującym europejską tożsamość okazuje się natomiast przechowana mimo wszechogarniającego rozpadu pamięć kulturowa, objawiająca się również jako fenomen implicytnie zakodowany w sposobie konstruowania narracji, który zdaje się orientować na przywrócenie i aktualizację zbiorowej świadomości w obliczu wyzwań i zagrożeń współczesnego świata.

W tak nakreślonym kontekście znaczeniowym warto usytuować kilka nośnych interpretacyjnie scen, miejsc szczególnej koncentracji sensu. Pierwszą z nich jest ukazany „od kuchni” reportaż telewizyjny z przywróconego po trzyletniej okupacji karnawału w Nadrenii Północnej-Westfalii. Reporter Richard Scholtz relacjonuje z Kolonii maskaradowy pochód Różowego Poniedziałku (Rosenmontag to kulminacyjny punkt kolońskiego karnawału), przypominając widzom o bolesnych wydarzeniach minionej wojny. Bohater, narzekając na polityków cierpiących na syndrom "krótkiej pamięci”, mówi o potrzebie pielęgnacji pamięci historycznej dla pomyślności przyszłych pokoleń, a także zaimplementowania poczucia dumy z młodego państwa i zaufania do prowadzonej przez nie polityki multikulturalizmu. Zorientowany na osiągnięcie tych celów dyskurs medialny wyraźnie eliminuje z pola widzenia konstytutywne dla karnawału cechy: ambiwalentny śmiech, ekscentryzm, skandal, nastawione na parodyjną delegitymizację systemu konwenansów i autorytetów. Zamiast tego powieściowa relacja $\mathrm{z}$ pochodu karnawałowego staje się narzędziem polityki historyczno-kulturowej, a w kolektywną świadomość wdrażane są nowe autorytety i schematy mentalne. Modelowe współistnienie kultury chrześcijańskiej i muzułmańskiej ma wyrażać się $\mathrm{w}$ parodyjnych figurach prezydenta $\mathrm{Ca}-$ simira von Lützowa i kanclerza Şafaka Baştürka, bohaterów wojennych, którzy zdołali odeprzeć natarcie talibów. Reporter Scholtz przeprowadza ponadto wywiady z innymi śmiałkami, wśród których znajdują się m.in. potomkowie jugosłowiańskich imigrantów i przedstawiciele mniejszości seksualnych, w tym Sabina Grgić - lesbijka, studentka wydziału humanistycznego. Pozornie spontaniczne rozmowy $\mathrm{z}$ tymi bohaterami również podporządkowane są polityce historycznej; widzowie bombardowani są szablonowymi hasłami typu „мир, завоеванный отцами в полях под Дуйсбургом", „одолеть коварного и сильного врага", „прославленный ас, воздушный гусар, защищавший небо нашей страны" ${ }^{4}$. Wyłaniający się z transmisji obraz powojennego świata wolno zatem postrzegać jako literacką transpozycję szeregu kolektywnych obaw i nadziei współczesności, dotyczących z jednej strony powrotu konfliktów zbrojnych do centrum Europy, separatyzmu i eskalacji islamskiego fundamentalizmu, z drugiej zaś solidarności w obliczu ataku fundamentalistów i możliwości jego od-

4 В. С о р о к и н, Теллурия, Москва 2013, s. 35-42. 
parcia oraz rozwoju konstruktywnej współpracy umiarkowanych wyznawców różnych wyznań. $W$ konstruowanej przez telewizję państwową atmosferze karnawałowy śmiech traci, jak zasygnalizowano, swoją ożywczą, ironiczną energię, przestając być wentylem bezpieczeństwa, ułatwiającym egzystencję $\mathrm{w}$ warunkach podporządkowania się regułom życia społecznego, i ograniczając się do naiwnej, bezpośredniej wesołości (choć przecież i we współczesnych, skomercjalizowanych kilońskich obchodach obecne są elementy satyry na aktualną rzeczywistość). Należy przy tym zastrzec, że karnawałowe antyzachowania są nieobecne $\mathrm{w}$ widzialnej przestrzeni medialnego obrazu karnawałowego pochodu, bo to wyłącznie na nim koncentruje się narracja. Eksponowaną nieautentyczność dyskursu potęguje zestawienie prowadzonej przez Scholtza relacji telewizyjnej z obrazem jego życia prywatnego. Za kulisami medialnego spektaklu rozgrywa się dramat jednostek - dziennikarz okazuje się narkomanem cierpiącym na zespół stresu pourazowego. $\mathrm{Z}$ jego trudnym charakterem dzielnie zmaga się pragmatyczna partnerka, pałająca niechęcią do kolońskich obchodów karnawału i określająca narrację polityki historycznej mianem „патриотическая чушь" 5 , której przekazywanie pozwala wszakże pokonać chwilowy kryzys finansowy i wpisać się w ramy nowego społeczeństwa.

Konstrukcja omawianego fragmentu pozwala określić opisane w nim zjawisko mianem dekarnawalizacji karnawału, którą wolno rozpatrywać $\mathrm{w}$ optyce minus-chwytu. Uprawnioną wydaje się mianowicie teza, iż wytracanie się pozytywnej energii masowego święta wiąże się z karnawałowym charakterem ogółu rzeczywistości, która w obliczu skrajnej heterogenizacji nie pozostawia już pola do buntu i ironicznego komentarza. W kreowanej w powieści pluralistycznej przestrzeni niemieckiego państwa, wywodzonej z ponowoczesnej kultury otwartości, przekory i demokratycznej konsumpcji, karnawał jest wszak stanem permanentnym, codziennym, traci więc sens jego czasowa celebracja; sam rytuał (jako zaledwie ślad pierwotnej obrzędowości) zostaje zatem wykorzystany do innych celów - instrumentalnie wpisany $\mathrm{w}$ oficjalne działania polityczne ${ }^{6}$. Co istotne, dekarnawalizacja karnawału nie oznacza bynajmniej rewitalizacji kultury powagi - możliwa wzniosłość musi $\mathrm{w}$ hurrapatriotycznym komentarzu medialnym ustąpić miejsca przesadnemu patosowi, sztuczności, sztampie, nastawionym na odgórną integrację masowego, niewymagającego odbiorcy wokół minimum wartości, jakim staje się bezpieczeństwo. Medialna inżynieria tożsamości operuje zatem zarówno płytkim śmiechem (przykładem

${ }^{5}$ Ibidem, s. 47.

${ }^{6}$ Oczywiście poza kontekstem literackim polityka historyczna jest naturalnym elementem polityki państwa, w danym wypadku zwracam jedynie uwage na rugowanie elementu ironicznej gry z obrzędów karnawałowych. 
może być moment apoteozy regionalnego piwa), jak i płytką powagą (cytowane sztampowe okrzyki); wymowna jest ponadto degradacja kultury wysokiej - przywoływany przez Scholtza fragment Fugi śmierci Paula Celana nie wynika z jego erudycji, lecz zostaje, dzięki nowej technologii, automatycznie wygenerowany $\mathrm{w}$ oku reportera; wszelkie poważniejsze dygresje zdradzające mentalną samodzielność bohatera są z kolei natychmiast przerywane przez dziennikarkę ze studia. Mimo kreowanej przez media pozytywnej atmosfery zwycięstwa mamy zatem do czynienia z faktyczną degradacją święta $\mathrm{w}$ takim sensie, $\mathrm{w}$ jakim jest nią nakreślona $\mathrm{w}$ Tellurii próba desemantyzacji karnawału i jego zaadaptowania na potrzeby mało przekonującej polityki historycznej.

W konstruowanym metakontekście degradacji masowego święta jako nośnika tożsamości kulturowej uwaga odbiorcy przenosi się ku tym sensotwórczym epizodom, które określić można mianem matych świąt ${ }^{7}$. Kontrapunktem dla medialnej oprawy karnawału w Kolonii jest polowa uczta dwóch psiogłowych podróżników - poety Romana i filozofa Fomy, którzy zbiegli z prywatnego teatru, gdzie byli zmuszani do pracy jako aktorzy, i zmierzają $\mathrm{w}$ kierunku Tellurii. Ich erudycyjną rozmowę można streścić jako zderzenie dwóch postaw wobec obserwowanego wokół kryzysu paradygmatu oświeceniowego, nawiązujące do modnej filozofii Petera Sloterdijka, w szczególności opozycji cynizmu i kynizmu8. Do postrzegania osobliwej biesiady jako święta skłania postawa Fomy - filozof nakłania swego towarzysza do celebracji posiłku i poddania mięsa obróbce termicznej, uznając to za przymiot ludzki (samą ucztę określa nobilitującym mianem trapezy). Foma nazywa siebie postcynikiem i przeciwnikiem bestializacji; zachęca on swojego towarzysza do przezwyciężania zwierzęcej natury i wewnętrznego samodoskonalenia na drodze ku duchowo-cielesnej (etyczno-estetycznej) doskonałości, powołując się na wymogi kontekstu kulturowego i konieczność zadośćuczynienia społecznym oczekiwaniom odnośnie do wizerunku poety. Bohater korzysta $\mathrm{z}$ instrumentarium pojęciowego Slo-

7 Wprowadzoną kategorię można traktować jako swobodne nawiązanie do pojęcia małej narracji w rozumieniu J.-F. Lyotarda, wraz z towarzyszącymi mu w myśli ponowoczesnej pozytywnymi konotacjami. Zob.: J.-F. L y o t a r d, Kondycja ponowoczesna: raport o stanie wiedzy, przeł. M. Kowalska i J. Migasiński, Warszawa 1997, s. 176.

${ }^{8}$ Krytykowany przez Sloterdijka współczesny cynizm jest oświeconą świadomością fałszywą - cechuje jednostki świadome rozpadu ideałów i wielkich celów, jednak konformistycznie układające się z kultywującym te iluzje społeczeństwem dla świętego spokoju i własnych korzyści. Postulowana przez niemieckiego myśliciela postawa kyniczna byłaby natomiast powrotem do cynizmu starożytnego, pryncypialnie bezczelnego i otwarcie demaskującego konformizm współczesnego cynika. Zob. szerzej: P. S 1 o t e r d i j k, Krytyka cynicznego rozumu, przeł. P. Dehnel, Wrocław 2008. 
terdijka również wtedy, gdy nazywa siebie i Romana ofiarami antropotechniki - swoistego treningu pozwalającego zachować człowieczeństwo i objąć kontyngencje ponowoczesnego istnienia ${ }^{9}$. Nonszalancki Roman sytuuje się z kolei po stronie miłego Sloterdijkowi kynizmu, akceptując własną dwoistą naturę i bez skrępowania konsumując ludzką padlinę, którego to procederu nie poczytuje za ujmę dla swej profesji. Sorokinowski kynik podpiera się zresztą bliską samemu autorowi tradycją poetów przeklętych, a konkretnie nazwiskiem Charlesa Baudelaire'a. W rozmowie pojawia się ponadto mniej bezpośrednie odwołanie do znanych wersów Anny Achmatowej („на поле брани лежат мозги, не ведая стыда"10), akcentujących egalitarną rozległość zainteresowań poezji. Roma, który najchętniej zaspokoiłby głód natychmiast, proces przygotowania posiłku nazywa „bzdurnym rytuałem”, włącza się wszakże w dialektyczną dysputę, przyznając, że jego marzenia związane są z ludzkim pierwiastkiem jego egzystencji, zdradzając oczytanie i humanistyczną wrażliwość (a także typowo ludzką predylekcję do konsumpcji alkoholu). W dalszej części osobliwego święta Foma, jakby na potwierdzenie swej przynależności do zakłamanych współczesnych cyników, po wygłoszeniu dydaktycznych formuł pod adresem „, towarzysza $\mathrm{w}$ antropotechnicznym nieszczęściu" wyjmuje wreszcie z plecaka ludzką głowę i wrzuca do wrzątku, by potem z nieskrywanym już apetytem skonsumować przygotowaną zupę, naigrywając się nieco $\mathrm{z}$ romantycznych inklinacji towarzysza. Spolaryzowane na początku postawy bohaterów zmierzają zatem ku spotkaniu: każdy z rozmówców wyraża gotowość podważenia swojej wyjściowej idei $\mathrm{w}$ toku intersubiektywnego dialogu, niejako asymilując oba pierwiastki autopercepcji. Na poły kanibalistyczna konsumpcja nie umniejsza przy tym wartości intelektualnej dyskusji, osadzając ją jedynie w iście Sorokinowskim kontekście hipernaturalistycznej cielesności. Sygnalizowany kontekst znaczeniowy pozwala uznać opisany fragment za swego rodzaju pars pro toto świata artystycznego Sorokina, zdolnego ulokować pewne wartości nawet $\mathrm{w}$ najgłębszych pokładach ciemnej materii. Nawet na polu bitwy, mimo panujących wojen, powrotu do feudalnego ucisku, (pozornej) degradacji ciała i ducha oraz przyzwolenia na kanibalizm, wśród psiogłowych istot nie ustaje bowiem intelektualna wymiana myśli pełna świadomych aluzji do europejskiej spuścizny kulturowej, rozpoznawalnych figur symbolicznych: zaznaczoną już bogatą intertekstualną przestrzeń opisywanej sceny uzupełniają m. in. odwołania do poezji rosyjskiej i radzieckiej, opery Richarda Wagnera Lohengrin oraz ikonicznych przedstawień świętego Krzysztofa ( $w$ tradycji wschodniej przed-

${ }^{9}$ Zob. szerzej: A. Ż y c h 1 i ń s k i, Making it explicit. Petera Sloterdijka anatomia antropotechnik, [w:] tegoż, Wielkie nadzieje i dalsze rozważania, Poznań 2013.

${ }^{10}$ B. С о р о к и н, op. cit., s. 202. 
stawiany właśnie z głową psa). Tak konstruowana linia interpretacji pozwala upatrywać $\mathrm{w}$ scenie nadzieję na przechowanie $\mathrm{w}$ mikroskali głębokich treści kulturowych, które tym razem pielęgnowane są oddolnie, na zasadzie dobrowolnej partycypacji (a nawet na przekór półzwierzęcej naturze), a nie poprzez skrajnie spłycający dyskurs medialny, narzucający skompromitowane metanarracje. Pożądana aktualizacja europejskiej tożsamości kulturowej staje się $\mathrm{w}$ bieżącej konstelacji możliwa na poziomie mikrowspólnot, tworzących ponadnarodową sieć lojalnościową.

Dyskretnie snuta antropologiczna refleksja oraz zagęszczenie sieci intertekstualnych asocjacji uprawnia ponadto do wysublimowania wartości naddanej opisywanego spotkania, nadania mu $\mathrm{w}$ toku interpretacji statusu bachtinowskiego со-бытия, a więc wydarzenia dialogowego, zorientowanego na wypracowanie podmiotowości $\mathrm{w}$ kontakcie $\mathrm{z}$ drugim człowiekiem ${ }^{11}$. To właśnie budowanie własnej godności wydaje się bowiem nadrzędnym celem wędrowców - swoją drogę nazywają oni "ucieczką z poniżającej przeszłości"; rejterada z teatru zyskuje rangę symbolicznego zerwania z koniecznością udawania kogoś innego na rzecz konstruowania własnej tożsamości, ku czemu jako erudyci mają wszak ogromny potencjał. Mentalna emancypacja wiąże się $\mathrm{w}$ danym wypadku $\mathrm{z}$ sygnalizowanym wyzwaniem asymilacji pierwiastka zwierzęcego i ludzkiego, które również wydaje się mieć szansę na realizację. Proces dialogicznego fundowania podmiotowości zostaje jednak zakłócony w kulminacyjnym momencie symbolicznego zawładnięcia wiedzą - przez odnalezienie w spożywanym mózgu kuli oraz tellurowego gwoździa, co przypomina odpowiednio o śmiertelności, kruchości życia oraz o możliwości spotkania z transcendencją. Moment ten okazuje się zgubny: jesteśmy świadkami swego rodzaju „zapomnienia” budzącej się w trakcie uczty autonomicznej podmiotowości i „przypomnienia sobie" celu wędrówki: osiągnięcia tellurowego transu, postrzeganego przez zagubionych wędrowców jako absolutny punkt oparcia, spełnienie mglistych marzeń o szczególnej mocy, nadczłowieczeństwie. Bohaterowie zaczynają jak gdyby deprecjonować swoje kompetencje, nie dostrzegają podmiotowości budzącej się hic et nunc w spotkaniu dwóch myślących jednostek, uzależniając osiągnięcie pełni szczęścia od kontaktu z gloryfikowanym półmetalem. Warto dodać, iż owo przesunięcie optyki uwypuklone zostaje przez zmianę $\mathrm{w}$ konstrukcji dialogu - intelektualnie nasycone, autoironiczne repliki przechodzą w naiwne okrzyki ku chwale cudownego telluru:

11 Zob.: М.М. Б а х т и н, Автор и герой в эстетической деятельности. Проблема aвmopa, [w:] źródło elektroniczne: http://mmbakhtin.narod.ru/probl.html (31.10.2015). Za zwrócenie uwagi na zagadnienie podmiotowości dziękuję dr Annie Katarzynie Przybysz. 
Роман. Так не хочется терять веру в мечту. Фома. Мечта всегда с нами. Она - наш Альтаир!

Роман. Мы возьмем этот гвоздь с собой?

Фома. Нет! (Бросает гъоздь в траву). Он пуст. Ибо уже сделал свое дело, подарил мечту воину. А нам нужны новые, сияющие гвозди. Этих гвоздей жаждут наши измученные мозги!

Роман. Гвозди сияющие, несущие радость и мощь.

Фома. Радость!

Роман. Мощь!12

Zarysowana możliwość interpretacji sytuuje epizod w szerszym kontekście Sorokinowskiej antropologii, jednym z głównych motywów twórczości Rosjanina jest bowiem zapoznanie osiągnięć mentalnej emancypacji jednostki $\mathrm{w}$ autodestrukcyjnej służbie wielkim narracjom (postrzeganej jako regres, reifikacja, dehumanizacja). O ile zatem małe święto uruchamiające oddolną intelektualną debatę rzeczywiście przejmuje $\mathrm{w}$ danym wypadku funkcję nośnika kulturowej tożsamości, o tyle bezwiednie akumulowana $w$ jego trakcie energia wydaje się powoli wytracana na rzecz nowego absolutu. Rozpatrując dany fragment w relacji do sceny degradacji karnawału, można wszelako zauważyć, że w toku uczty psiogłowych intelektualistów energia święta jest faktycznie gromadzona (czy też wyzwolona $\mathrm{w}$ procesie intersubiektywnego dialogu), podczas gdy koloński karnawał odbiorca ma okazję poznać już jako święto zdegradowane, energetycznie puste. Pewną nadzieję na autorefleksję dają dyskretne ślady - podróżnicy zasypiają syci i objęci; w obu fragmentach rozpoznane zostaje niebezpieczeństwo uległości wobec wielkich projektów ideologicznych, pretendujących do organizacji zbiorowej wyobraźni (polityka historyczna, moc telluru). Wedle słów Fomy „мечты изматывают” (wyczerpują, wykańczają). Dokładnie tego samego określenia używa Silke, opisując męczące działanie karnawału i wykazując duży stopień sceptycyzmu wobec medialnej manipulacji pamięcią ${ }^{13}$. Akcentowane zmęczenie wolno rozpatrywać jako sygnał, iż bohaterowie są świadomi destrukcyjnej energii nowych wielkich narracji, nastawających na ich indywidulną autonomię.

Fragmentem dopełniającym kontekst małego święta może być scena z życia petersburskiej bohemy - zgromadzeni dekadenci (notabene również cytujący Baudelaire'a) pragną w osobliwy, egocentryczny sposób odtworzyć obraz Edvarda Muncha Bohema Krystianii: przyjmują analogiczne pozy i za pomocą "mądrali" (w oryg. ros. умница - rodzaj futurystycznego tabletu) robią sobie "selfie" na tle obrazu, by z niemałą satysfakcją

12 В. С о р о к и н, op. cit., s. 208. Zabieg stopniowego ubożenia języka bohaterów ulegających zgubnemu wpływowi ideologii stosuje Sorokin również w Trylogii (powieści Lód, Bro i 23 000).

13 Por.: В. С о р о к и н, op. cit., s. 46 i 213. 
skonstatować tożsamość obu dzieł i oddać się obowiązkowej orgii. Parodystyczny wydźwięk sceny nie deprecjonuje obrzędu, przeciwnie - dzięki zabiegowi rekontekstualizacji i osobistemu, familiarnemu stosunkowi bohemy do dzieła wybitnego malarza wolno mówić o aktualizacji konceptu, przechowaniu artefaktu wysokiej kultury $\mathrm{w}$ indywidualnej pamięci, cennym oddolnym zaangażowaniu i woli partycypacji w procesie odnawiania tradycji.

Przywołane powyżej małe święta psiogłowych intelektualistów i bohemy przyszłości można uznać za renobilitację karnawału, jak również potwierdzenie ponowoczesnej relokacji tej kategorii ze sfery temporalnej obrzędowości na poziom codziennej egzystencji i światoodczucia. Eksplicytnie wybrzmieć w tym miejscu powinny takie sygnalizowane już karnawałowe cechy obu opisywanych fragmentów, jak: akcentowanie dialogowego charakteru prawdy, zniesienie ograniczeń (np. między zwierzęcością a humanizmem $\mathrm{w}$ dialogu cynocefałów oraz między oryginałem a kopią w kulturalno-cielesnej orgii bohemy) i ironiczny (ale zarazem dowartościowujący) stosunek do tradycji - ambiwalentny śmiech staje się $\mathrm{w}$ tym zakresie strategią reakcji na światowy kryzys i motorem aktualizacji tożsamości kulturowej.

W podsumowaniu rozważań wolno uznać powieść Telluria za afirmacyjny manifest przynależności do europejskiej przestrzeni kulturowej, pewien hołd wspólnej spuściźnie, współkonstruujący sieć twórczych impulsów, łączącą rosyjski i europejski dorobek artystyczny. Wyposażenie bohaterów w zaakcentowaną tu kompetencję świadomego kultywowania pamięci kulturowej, często na przekór społeczno-politycznemu zamętowi bądź cielesnym ograniczeniom, wzmacnia intertekstualny potencjał Sorokinowskiej powieści i jest wyrazem dowartościowania literatury, twórczości artystycznej, namysłu filozoficznego, które mają nadzieję zachować swe doniosłe znaczenie mimo ponowoczesnego rozpadu innych układów odniesienia. Parodyjna wymowa intertekstualnych nawiązań, podobnie jak podejmowana na metapoziomie polemika Sorokina ze sztampowym, usakralizowanym wizerunkiem twórców i ich dzieł, obniżanie patosu pierwowzorów nie kwestionuje ich wartości, lecz wiedzie ku ożywczej rekontekstualizacji, prowokującej odbiorcę do intelektualnego wysiłku. Właściwe Tellurii zogniskowanie fabuły na europejsko-rosyjskim obszarze cywilizacyjnym zyskuje wreszcie szczególną wymowę w relacji do bieżących wydarzeń politycznych. Sytuując rozważania o przyszłości Rosji w kontekście paneuropejskim, Sorokin po raz kolejny ujawnia oblicze rosyjskiego Europej$c z y k a, \mathrm{w}$ równym stopniu zainteresowanego losami własnego kraju i całego kontynentu, narcystycznym projektom izolacji przeciwstawiającego humanistyczne poczucie ponadnarodowej lojalności. Wolno przy tym mówić o pewnym elitaryzmie Sorokina, który w obliczu powszechnej degrengo- 
lady, postępującej intelektualnej degradacji, zdaje się poszukiwać możliwej strategii funkcjonowania liberalnie nastrojonego intelektualisty, odnajdując go właśnie w ożywczym dialogu jednocześnie zaangażowanych i zdystansowanych (wobec metanarracji) jednostek.

\section{Bibliografia}

L y o t a r d J.-F., Kondycja ponowoczesna: raport o stanie wiedzy, przeł. M. Kowalska, J. Migasiński, Warszawa 1997.

Postmodernizm a filozofia. Wybór tekstów, red. S. Czerniak, A. Szahaj, Warszawa 1996.

S l o t e r d i j k P., Krytyka cynicznego rozumu, przeł. P. Dehnel, Wrocław 2008.

$\mathrm{S}$ z a h a j A., Ponowoczesność - czas karnawału, postmodernizm - filozofia błazna, [w:] Postmodernizm a filozofia. Wybór tekstów, red. S. Czerniak, A. Szahaj, Warszawa 1996.

Ż y c h 1 i ń s k i A., Making it explicit. Petera Sloterdijka anatomia antropotechnik, [w:] tegoż, Wielkie nadzieje i dalsze rozważania, Poznań 2013.

Б а х т и н М.М., Автор и герой $b$ эстетической деятельности. Проблема автора, [w:] źródło elektroniczne: http://mmbakhtin.narod.ru/probl.html (31.10.2015).

М а р у с е н к о в М.П., Абсурдопедия русской жизни Владимира Сорокина. Заумь, гротеск и абсурд, Санкт-Петербург 2012, s. 5-10.

Н е ф а г и н а Г., Возвращение вперед Владимира Сорокина, или от деструкции - к конструкции (анти)утопического мира, [w:] От модернизма к постмодернизму. Русская литература ХХ-ХХІ веков. Сборник статей в честь проф. Халины Вачкелевич, ред. А. Скотницка, Я. Свежи, Краков 2014, s. 558.

От модернизма к постмодернизму. Русская литература ХХ-ХХІ веков. Сборник статей В честь проф. Халины Вашкелевич, ред. А. Скотницка, Я. Свежи, Краков 2014.

С о р о к ин В., Теллурия, Москва 2013. 